OPEN ACCESS

Edited by:

Luciane M. Perazzolo,

Federal University

of Santa Catarina

Brazil

Reviewed by:

Jing Xing,

Ocean University of China,

China

WeiWei Li,

East China Normal University,

China

*Correspondence:

Younes Bouallegui

bouallegui_younes@outlook.com

Specialty section: This article was submitted to

Comparative Immunology,

a section of the journal

Frontiers in Immunology

Received: 14 February 2021 Accepted: 27 April 2021

Published: 13 May 2021

Citation:

Bouallegui Y (2021) A Comprehensive Review

on Crustaceans' Immune System With a Focus on Freshwater Crayfish in Relation to Crayfish Plague Disease.

Front. Immunol. 12:667787.

doi: 10.3389/fimmu.2021.667787

\section{A Comprehensive Review on Crustaceans' Immune System With a Focus on Freshwater Crayfish in Relation to Crayfish Plague Disease}

\author{
Younes Bouallegui *
}

LR01ES14 Laboratory of Environmental Biomonitoring, Faculty of Sciences of Bizerte, University of Carthage, Bizerte, Tunisia

Freshwater crayfish immunity has received great attention due to the need for urgent conservation. This concern has increased the understanding of the cellular and humoral defense systems, although the regulatory mechanisms involved in these processes need updating. There are, however, aspects of the immune response that require clarification and integration. The particular issues addressed in this review include an overall description of the oomycete Aphanomyces astaci, the causative agent of the pandemic plague disease, which affects freshwater crayfish, and an overview of crustaceans' immunity with a focus on freshwater crayfish. It includes a classification system of hemocyte sub-types, the molecular factors involved in hematopoiesis and the differential role of the hemocyte subpopulations in cell-mediated responses, including hemocyte infiltration, inflammation, encapsulation and the link with the extracellular trap cell death pathway (ETosis). In addition, other topics discussed include the identity and functions of hyaline cells, the generation of neoplasia, and the emerging topic of the role of sessile hemocytes in peripheral immunity. Finally, attention is paid to the molecular execution of the immune response, from recognition by the pattern recognition receptors (PRRs), the role of the signaling network in propagating and maintaining the immune signals, to the effector elements such as the putative function of the Down syndrome adhesion molecules (Dscam) in innate immune memory.

\section{Keywords: hemocytes, hyaline cells, hematopoiesis, etosis, Aphanomyces astaci}

\section{INTRODUCTION}

The large decline in the number of the European indigenous freshwater crayfish caused by repetitive outbreaks has brought such organisms close to extinction (e.g., Astacus astacus) (1-3). Scientists have raised their concerns about the natural stock of endangered crayfish species, boosting investigations to uncover the causes for conservation purposes. The crayfish plague disease, reported as the main threat to this species is linked to the accidental or commercial relocation of invasive species like the North American species (e.g., Pacifastacus leniusculus and Procambarus clarkii), a vector of the oomycete Aphanomyces astaci, the causative agent of the disease (4-6). The disease's most characteristic symptoms are common spots of melanin in the cuticle of infected or 
dead individuals. Extensive studies have demonstrated that such melanin spots (i.e., melanization) are the result of the immune response aiming to enclose the pathogen in melanin sheaths to prevent it from invading and grow into the hemocoel (7-11). A. astaci is capable of infecting indigenous and invasive crayfish species equally, however, the latter are less vulnerable $(P$. leniusculus, C. quadricarinatus, and Procambarus clarkii) (1, 8, 12). However, vulnerable indigenous European species like $A$. astacus, mostly showed very few or almost no formation of melanized spots, while the development of hyphae was recorded. The differential immune response between indigenous and invasive species is among the main clues that need to be studied and has driven investigations related to crayfish immunity $(4,13,14)$. In this context, the activation of the prophenoloxidase (ProPO) system, the process responsible for melanin formation, has been extensively studied (15-21). Interestingly, previous studies have demonstrated that encapsulation is a mandatory process that triggers the activation of the ProPO system (22-24). However, functional mechanisms linking cooperative actions of the humoral- and cell-mediated responses of the innate immunity, need to be considered further $(18,25)$. In doing so, the relationships between melanization, pathogen encapsulation, and immune cell production (i.e., hematopoiesis) need to be elucidated and integrated to the reported decrease in the number of circulating hemocytes (i.e., total hemocyte count [THC]), during infection (14-17, 26-31). In this context, the immune modulation of freshwater crayfish against $A$. astaci is still hampered by a smaller integration of the components of functional defenses $(17,32)$. In this review we tried to compile different components of the crayfish immune response, related strategies, and debated topics in one paper, aiming to make a comprehensive and integrated synopsis of the crayfish immune system available that might advance the understanding of this topic.

\section{APHANOMYCES ASTACI: CAUSATIVE AGENT OF THE CRAYFISH PLAGUE DISEASE}

The pathogen Aphanomyces astaci (Shikora, 1906) is a pathogenic oomycete native to North America and only colonizes aquatic decapods. It is listed among the world's 100 worst invasive alien species $(3,33)$. The oomycetes, the so-called water molds, belong to the genus Aphanomyces and are members of the Ooomycotina, Eumycota family, which are not true fungi but more closely related to brown algae and diatoms $(8,33)$. A. astaci is a non-septate, branching fungus belonging to the Saprolegniaceae family, with 7-10 micron thick hyphae and biflagellate zoospores assuring their asexual reproduction. The life cycle comprises a relatively short-lived swimming zoospore stage that ends with encasement (12). Encysted spores drop or retract their flagella to be able to encase into the cell wall covered by sticky substances assuring their adherence to the host. Shortly after, a period of hyphal growth within the host starts and the emerging hyphae penetrate the host's cuticle $(8,12)$. So far, 5 strains of $A$. astaci have been identified and characterized to belong to 5 different genotypes thanks to random amplified polymorphic DNA (RAPD) $(2,34,35)$. Such genotypes are referred to as groups 1, 2, 3, and 4, or as the Astacus strain, the Pacifastacus strain I, the Pacifastacus strain II, and the Procambarus strain, which can be abbreviated to As, PsI, PsII, $\mathrm{Pc}$, and Or, respectively. The As-strain is referred to as Astacus, and is the first genus from which this strain was identified since the original host has not yet been identified or found. The original host of PsI and PsII is the crayfish species Pacifastacus leniusculus (Dana, 1852), the original hosts of the Pc and Or genotypes are Procambarus clarkii (Girard, 1852), and Orconectes limosus (Rafinesque, 1817), respectively (2, 10, 34, 36, 37). The As-genotype was thought to be responsible for the first outbreaks in Europe following its transmission in the $19^{\text {th }}$ century. In contrast to North American crayfish species, which maintain a relatively stable interaction with $A$. astaci, Asian, Australian, and European crayfish species are highly susceptible to the pathogen. However, recent reports have recorded differential virulence of different $A$. astaci strains to different European species $(36,37)$. Laboratory experiments demonstrated that PsI was found to be the most virulent causing all the noble crayfish Astacus astacus to die within few days, while the As strain was found to be the less virulent in general (36). Overall, a devastating impact on European-native crayfish species has been recorded, which drastically declined their natural stock and so far has led to numerous species being listed at "risk of extinction" (34). Many studies have attributed this drastic effect to the inability of such species to respond efficiently to prevent the spread of $A$. astaci. Thus, the oomycete is capable of killing almost $100 \%$ of the individuals within an infected population in a few days $(8,10,12)$. Infected individuals of vulnerable species are incapable of preventing hyphae growth in their hemocoel, in contrast to resistant species, which have been reported to extensively respond by triggering their immune system after interaction with the oomycete cell wall (1,3- $\beta$-glucan). This stimulates the activation of the prophenoloxidase system producing cytotoxic compounds and melanin to ensure the encapsulation of the pathogen in the cuticle and prevent it from completely colonizing the hemocoel $(8,34)$. There is no efficient treatment for the disease, nor has there been a successful strategy recorded to help mitigate the pathogen's effects. However, a deep understanding of defense mechanisms, which has greatly increased nowadays, is still the most promising way to design an accurate strategy to overcome this threatening situation.

\section{EPIDEMIOLOGY AND PREVALENCE OF THE PATHOGEN APHANOMYCES ASTACI}

Aphanomyces astaci outside of North America is considered as an alien species. The first evidence for its introduction into Europe marked by the first mass mortality among European native crayfishes occurred in 1859 in the Po River basin in northern Italy, which has deeply threatened populations of the Italian white-clawed crayfish Austropotamobius pallipes (38). 
These followed later by several outbreaks in the Plateau des Langres at the Franco-German frontier area, in 1874 (38). The following decades, witnessed steady spreads of the pathogen to other European countries following main two directions, down the Danube river into the Balkans ending in the Black Sea, and across North Germany into Russia. From there, the distribution occurred toward the south again to the Black Sea, and onto north-west to Finland and, in 1907, to Sweden. And since, that time it has spread across most of Europe. However, in 1960s, the first pandemics were reported in Spain, and two decades later the disease spread far to the British Isles, Turkey, Greece and Norway (39). Currently, the distribution of A. astaci, is confirmed to be present in other continents rather than native, and classic localities across Europe, like South America, Japan (40). Introductions of invasive crayfish species in many sites around the world for aquaculture purposes have been usually found to be coupled by A. astaci. However, no further data has been recorded about the distribution of A. astaci in Africa, Central America, South America, and other parts of east and south Asia (40). Australia and New Zealand have not experienced any outbreaks of crayfish plague to date and are currently considered plague free area (40). The actual distribution of A. astaci is therefore likely to be far broader than the distribution table would suggest.

Very recently, the occurrence of chronic infections in native European crayfish populations were documented, however such phenomenon still newly reported, and underlying mechanisms and factors remain scarce and need to be investigated further (1, $11,37)$. Recent assessments on the potential of freshwater crabs, and shrimp $(11,37,41)$ to be as alternative hosts have been conducted to rule out non-lethal effects in the absence of any mass mortality. The following is an integrated illustration of the recent findings on the crayfish immune system.

\section{GENERAL DESCRIPTION OF CRAYFISH IMMUNITY}

Like all invertebrates, crustaceans, including crayfish, only rely on innate immunity, which constitutes humoral- and cellularmediated responses (Figure 1) (17, 18, 29, 30, 42). Lack of acquired (specific) immune response in crayfish is due to the lack of myeloid lineage cells being able to produce immunoglobulins (specific antibodies) against specific pathogens in the event of

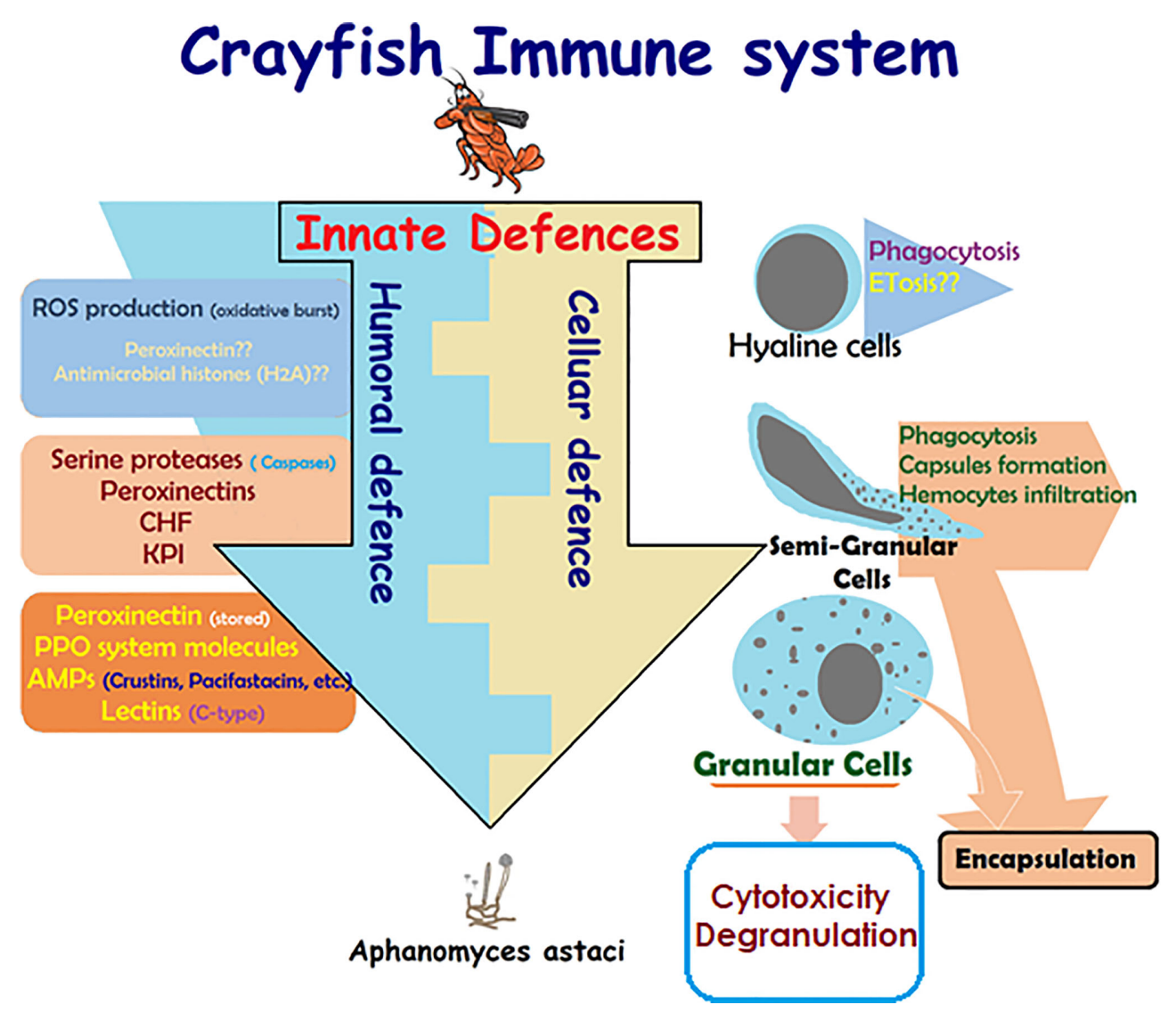

FIGURE 1 | Schematic presentation of crayfish immune response. Presentation of the main constituents of crayfish immune response alongside the cooperative action of the cellular-mediated and humoral-mediated responses and their corresponding factors $(4,5,14,17,18,26,28-30,42-54)$. 
repetitive infections (lack of memory). This lack of acquired immune response was found to be balanced by the enrichment of different cell-mediated strategies and several multi-type humoral factors, both constituting the innate defenses of the crayfish immunity (Figure 1) [e.g., multiple pathogen recognition receptors (PRRs)] $(28,42)$. These defenses are activated in a cooperative way in order to initiate effective defensive actions and can be classified according to two main responses: a humoral-mediated response involving humoral factors produced and released by the immune cells (antimicrobial peptides, hydrolytic enzymes, and molecules of the ProPO system, etc.), and a cell-mediated response that requires a direct action of the cell itself, such as phagocytosis, initiating the cell death pathway mechanisms (e.g., cytotoxicity, encapsulation) (Figure 1).

\section{Cell-Mediated Immune Response}

Cell-mediated responses require the direct action of the cell itself to neutralize alien invaders through mechanisms like phagocytosis, cell death pathways (e.g., apoptosis and autophagy), and inflammatory response (e.g., nodule formation and encapsulation). These strategies share a common prerequisite, which is hemocyte infiltration (hemocytosis), or the excessive migration of hemocytes from circulation to the infection site.

Changes in hemocytes' shape and/or features, in addition to surveying the total hemocyte number (THC), and differential hemocyte count (DHC), as well as the assessment of defensive activities like phagocytosis, cell viability, cytotoxicity, and different physiological changes, have been considered useful assays to investigate the crayfish immune response modulation (4, 26, 43-45). Hemocytosis requires extensive recruitment and infiltration of hemocytes into tissues where infections/stress have been detected $(25,30,32,55,56)$. Hemocyte infiltration may result in structural modifications of the histology of target tissue near the infection-surrounding microenvironment (56-66). Inflammatory response and histopathological assessments linked to hemocyte infiltration have been integrated into a single quantitative index using multiple histopathological traits for a more sensitive discrimination of the health status of assessed organisms like bivalves and fish aiming to develop an accurate system for assessing the health status of farmed animals (67-70). However, very few studies have been conducted on crayfish histopathology. Interestingly, studies using hemocyte parameters as a tool for assessing the modulation of the immune response in crustacean (mainly THC and DHC describing the fall in the number of circulating hemocytes due to their recruitment to infected tissues, to block pathogens from disseminating the hemocel), could be inter-correlated with quantitative histopathological assessments for more accurate hemocyte parameter data and integrative conclusions (4, 14, $15,18,24,26)$.

It is worth noting that the activation of melanin production by the ProPO system in crustacean defenses might be disrupted due to a lack of the appropriate number of hemocytes needed to fulfill such a role. This finding has been highlighted in Astacus astacus infected with Aphanomyces astaci, and has been linked to the lack of melanization in infected tissues that present hyphae development, which is not the case in invasive species like Pacifastacus leniusculus (species showing resistance to $A$. astaci) $(4,5,46)$. In this context, it would be interesting to illustrate the characteristics of hemocytes (and their different sub-populations), the key element of the crayfish immune response, which will be detailed in the following sections.

\section{CLASSIFICATION OF HEMOCYTE SUB-POPULATIONS}

\section{Morphological Characterization/ Classification}

Hemocytes, the key element of the crayfish immunity, participate in almost every defensive activity through direct action (e.g., phagocytosis, capsule formation), in addition to their production of most humoral factors (17). Hemocytes have been described and characterized since the early 1880 s by Carus as reported in (47). Hemocyte sub-populations were classified in general following morphological characterization according to the size of the cell, and the structural complexity of their cytoplasm (i.e., nucleus/cytoplasm ratio and the presence/absence of granules) $(15,24,26,71)$. Such characterization was mostly consolidated by a functional/cytochemical classification of each subpopulation (i.e., dependent on the main defensive action and/ or enzymatic activity through their enclosed granules, like peroxidase) (72-74). Last but not least, despite the significant progress recorded in these studies, the final number of crayfish hemocyte subpopulations has not yet been firmly determined. However, the oldest and most accepted clustering system presents three hemocyte sub-types: hyaline cells (HC) also called hyalinocytes, semi granular cells or hemocytes (SGC), and granular cells or hemocytes (GC), also called granulocytes $(26,48,49)$. The general characteristics are summarized in Table $\mathbf{1}$ below. Hyaline cells (HC) are described as the smallest cell type,

TABLE 1 | Summary of the three hemocyte sub-populations' characteristics.

\begin{tabular}{|c|c|c|}
\hline $\begin{array}{l}\text { Hemocyte } \\
\text { sub- } \\
\text { populations }\end{array}$ & Size (mean Ø) & $\begin{array}{c}\text { Characteristics } \\
\text { (structural complexity of cytoplasm) }\end{array}$ \\
\hline $\begin{array}{l}\text { Hyaline cells } \\
\text { (HC) }\end{array}$ & $10 \mu \mathrm{m}$ & $\begin{array}{l}\text { - Oval-shaped cells } \\
\text { - High nucleus-to-cytoplasm ratio } \\
\text { - Euchromatic centered nucleus } \\
\text { - Very few granules }\end{array}$ \\
\hline $\begin{array}{l}\text { Semi-granular } \\
\text { cells } \\
\text { (SGC) }\end{array}$ & $15 \mu \mathrm{m}$ & $\begin{array}{l}\text { - Low nucleus-to-cytoplasm ratio } \\
\text { - Elongated cells } \\
\text { - Large central nucleus } \\
\text { - Well-developed organelles (rough } \\
\text { endoplasmic reticulum) } \\
\text { - Numerous granules }\end{array}$ \\
\hline $\begin{array}{l}\text { Granular cells } \\
\text { (GC) }\end{array}$ & $21 \mu \mathrm{m}$ & $\begin{array}{l}\text { - Very low nucleus-to-cytoplasm ratio } \\
\text { - Spindle-shaped cells } \\
\text { - Enclosed nucleus; finely dispersed } \\
\text { nucleoplasm } \\
\text { - Large, well developed, structureless } \\
\text { lemon-like granules }\end{array}$ \\
\hline
\end{tabular}


while SGC typically feature an elongated shape. On the other hand, GC is described as the largest cell-type (43-46, 50, 51).

\section{Functional Characterization}

Functional activities of each hemocyte sub-type still are still the cause of some controversy $(5,14)$. This classification started to be elucidated by the early 1980s, however, separation techniques developed by Smith and Söderhäll at that time (1983) greatly advanced the detailed description of said functional activities (26). In this context, hyaline cells were described as phagocytic cells, semi granular cells were the main type ensuring encapsulation, and granular cells were mainly specialized in storing/releasing active molecules such as prophenoloxidase (pro-PO) system molecules within/from their well-developed granules $(14,15,18,24,26,27)$. However, all the sub-types mentioned were reported to be involved in the immune response with differential efficiencies toward mechanistic processes (18, 43, 45, 52-54). For example, for the most studied crayfish species (e.g., Astacus astacus, Pacifastacus leniusculus, Cherax quadricarinatus, and Procambarus clarkii), semi granular cells are described as the most important family in immune reactivity, involving capsule formation, encapsulation and assuring moderate phagocytic activity in addition to melanization through activation of ProPO cascading reactions (4, 14, 43, 45). ProPO activation is the main role of granular cells that do not present any phagocytic activity. The phagocytic function has been mainly allocated to hyaline cells (Figure 1). Unfortunately, many investigations (in vitro and in vivo) reported controversial data about the functional activity of hyaline cells $(43,45)$ and this is due to their very small presence in circulation. The scarce presence/putative function of hyaline cells and their importance has been exacerbated by the lineage paradigm of different types of immune cells, which consists of immune cell proliferation exclusively occurs in the hematopoietic tissue, therefore only very well differentiated and mature cells are released into circulation. Mature semi-granular as well as granular cells cannot be fully activated until released into circulation $(47,53$, 75). Unfortunately, $\mathrm{HC}$ are cells with the characteristics of immature undifferentiated cells (presenting proliferative phenotype, expressing PCNA; commonly called prohemocytes). HC, have been described to be released under certain circumstances, mainly after an immune challenge (46, 47 ) and so they have drawn attention to the existence and functions of such cell types (detailed in the following sections).

\section{Molecular Markers of Different Hemocyte Sub-populations}

Further, many transcriptomic and proteomic studies have helped classify hemocyte cell-types, following specific molecular markers expressed by each type, and have improved their functional characterization $(5,46,76)$. The PIRunt transcription factor has been reported as not being expressed in less mature cells, whereas it is marked simultaneously with the ProPO in the SGC and CG. More extension of ProPO to GC has been demonstrated. Furthermore, immunohistochemical studies reported the presence of superoxide dismutase (SOD) in SGC and GC, however, mRNA expression studies demonstrated that GC produces SOD (as monomers), which attaches to the outside of SGC (dimeric). More specifically, a Kazal-type proteinase inhibitor (KPI) and crustacean hematopoietic factor (CHF) were reported as being exclusively expressed by SGC (more details can be found in $5,73,62,76)$. Very recent studies have shown that hemocytes of the freshwater crayfish P. leniusculus express two types of transglutaminases, commonly named Pl_TGase1 and Pl_TGase2, and have evidenced that such TGs are specific to different hemocyte sub-populations (77). Pl_TGase1 was only expressed in SGC, but not expressed by all SGCs, and Pl_TGase 2 was only expressed in GC, and again not expressed by all GCs (77).

It's worth to note that benefit from advanced single-cell RNAsequencing (scRNAseq) technologies, in recent years, provide substantial improvement in reporting the hemocyte sub-type of the fly Drosophila, which has been largely renewed from only three sub-types: plasmatocytes, crystal cells, and lamellocytes to generating a comprehensive gene expression profiles for the drosophila circulating' hemocytes. In fact, Fu et al. have identified two new hemocytes' sub-types in Drosophila: thanacytes and primocytes with differential sets of genes (78). However, thanacytes expresses genes involved in distinct responses to different types of bacteria, while primocytes expresses cell fate, and signaling genes, potentially involved in keeping stem cells in the circulating blood. In addition to four other novel plasmatocytes subtypes (Ppnp, CAH7p, Lspp and reservoir plasmatocytes), each with unique molecular markers and distinct predicted functions (78). Further study conducted by Tattikota et al., aimed to use scRNAseq in mapping hemocytes across different inflammatory conditions in larvae. Subsequently, different genes expression-based states of plasmocytes have been resolved (79). In addition, a rare subsets of crystal cells expressing the fibroblast growth factor (FGF) ligand branchless, and lamellocytes expressing receptor breathless, have been reported. FGF components are required for mediating effective immune responses against parasitoid wasp eggs. As perspective, scRNAseq analysis consists a very urgent needed analysis that should be performed to decipher the gene expression profiles for a systems-level understanding of the diversity of crayfish hemocytes, and their functions.

\section{Production of Hemocyte Sub-populations: The Hematopoiesis}

Hematopoietic processes are among the most studied and have been really well described in studies related to crayfish immunity, aiming to decipher mechanisms underlying insufficient immune response against diseases like the plague disease (75, 80-82). Overall, investigations conducted by Söderhälls (Kenneth and Irene) and coworkers, resulted in an almost complete overview of molecular mechanisms that generate different hemocyte subfamilies $(47,53,82)$. In brief, the hematopoietic tissue in $P$. leniusculus contains four to five cell lineages arranged in lobules surrounded by connective tissue localized starting around the brain and following the ophthalmic artery to the posterior HPT, and ending by covering the dorsal part of the stomach (Figure 2) 

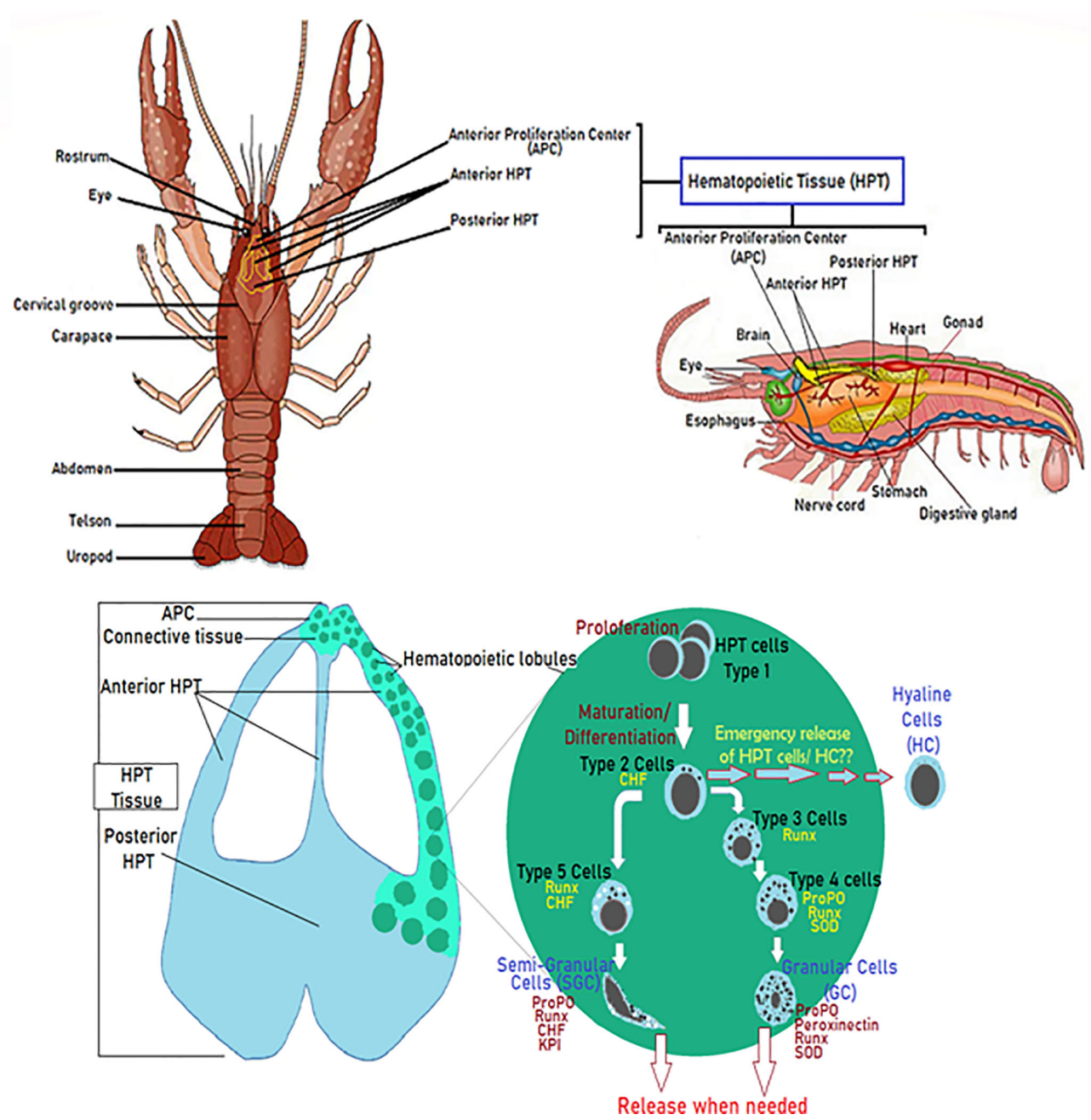

FIGURE 2 | Diagram of the hematopoietic tissue (HPT) illustrating the hematopoiesis' mechanistic steps. Schematic localization and presentation of the different parts of the HPT and the hematopoietic lobules illustrating the different phases of hemocyte production and how different cell types (Type I-V) acquire their specific molecular markers (47, 53, 75, 80-84).

$(47,53)$. HPT cells are clustered into lobules of 10 cell clusters for each lobule $(47,75,80,83,84)$. Cell morphology within such lobules is similar to different areas of the posterior HPT, with low mitotic activity in the center tissue that surrounds the ophthalmic artery. In contrast, high mitotic activity has been detected along the edges of HPT and the anterior proliferation center (APC), (Figure 2) $(47,75,83)$. HPT cells clustered into as type I to type V cells, with type I have the characteristics of undifferentiated cells without or with few granules (high mitotic figures and expression of PCNA), located in the apical part of the lobule where proliferation (extensive division) of precursor/stem cell occurs. Tending towards the center of the lobule, cells being more determined, and differentiated. Type II-IV cells are distally arranged starting with the type II cells, all presenting granules. Type III and IV found between lobules separated from each other, do not show divisive activities and ready to be easily freed as mature hemocytes into circulation $(47,82)$. Type $\mathrm{V}$ showed granules morphologically distinct from other types (Figure 2) $(47,75,80,82,83)$.

The hematopoiesis involves several key molecular factors like Astakines (1 and 2), cytokine-like proteins that contain a prokineticin domain $(\mathrm{PK})$, and playing the role of the growth factor hormone to stimulate the production and release of new hemocytes into circulation. Astakines acts through the reduction of the activity of transglutaminase (TGs) (Figure 3) (75, 83-89). TGs are Ca2+-dependent cross-linking enzymes with substrate is the type IV collagen, involved in coagulation and controlling hematopoiesis and extracellular matrix organization in crayfish $(84,88,91,92)$. TGs aims to inhibit stem cell differentiation and migration, which is closely dependent to ROS signaling (Figure 3). Astakine 1 was shown to stimulate differentiation along with SGC, through inducing the crustacean hematopoietic factor (CHF) to inhibits stem cell apoptosis and stimulates their differentiation and migration (75). Although, Astakine 2 most 


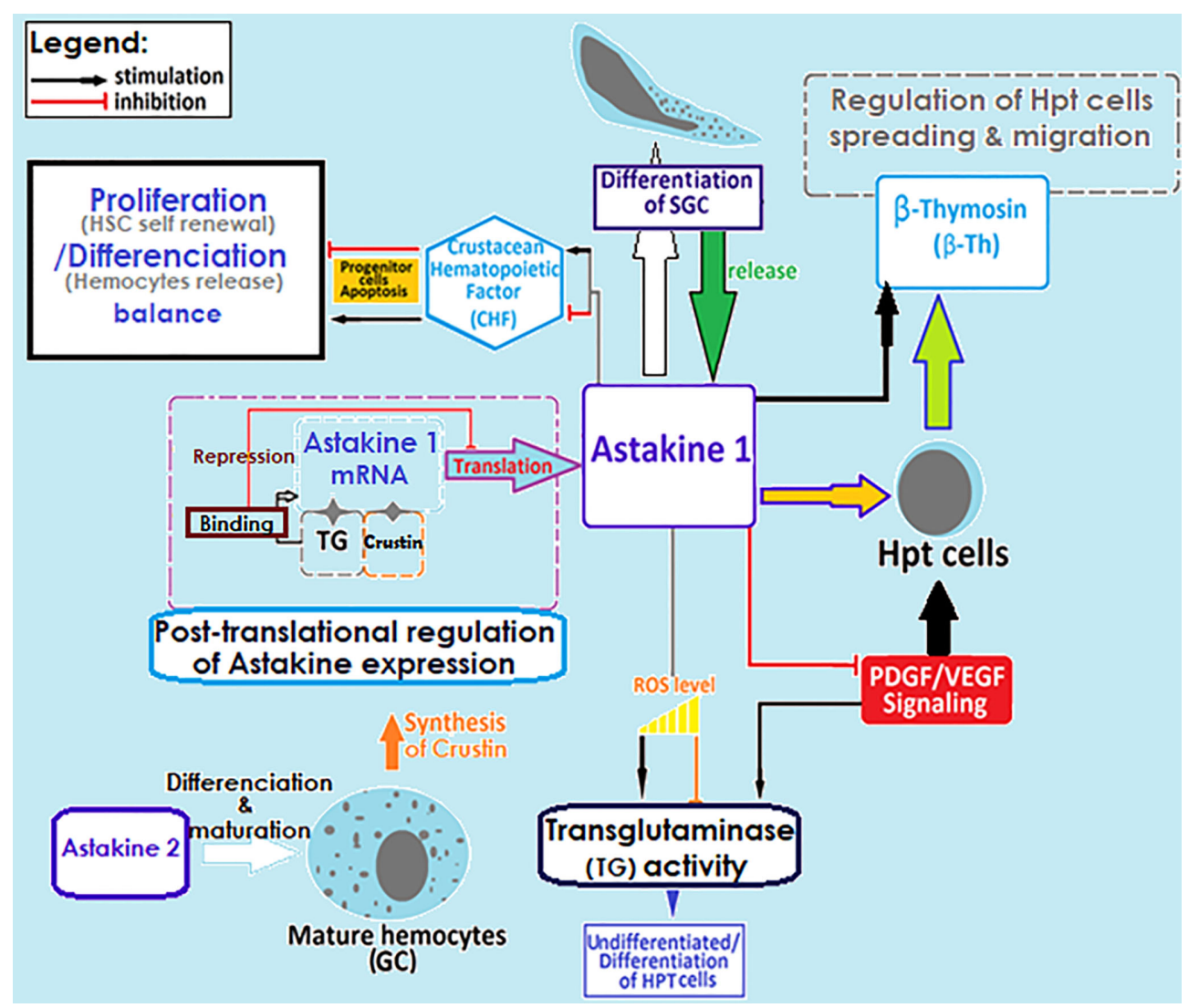

FIGURE 3 | Regulation of crayfish hematopoietic mechanisms. Molecular factors involved in the regulation of hemocyte production. SGC, semi granular cells; GC, granular cells; TG, transglutaminase; ROS, reactive oxygen species; HPT cell, hematopoietic cells; HSC, hematopoietic stem cells (29, 45, 47, 75, 83-97).

probably plays a role in the differentiation of GC $(47,75,89)$. Astakine expression and release were reported to be induced by a bacterial infection (LPS), fungal challenge, and tissue injury (84, $86,87,91)$. Moreover, crayfish' hemocytes reported as to be precursor for new neuron formation, and renewal of the nervous system in adult crayfish (93-95). Also, $\beta$-thymosin proteins are known for their actin-binding activity, and have been reported to interfere with Astakine in inducing hemocytes production and migration from the HPT (Figure 3) (96). In this same context, it is important to highlight the role of transglutaminase and crustin, a cysteine-rich anti-microbial peptide, as RNA binding proteins with a down-regulation role in post-transcriptional regulations for Astakine 1 expression $(47,97)$ (Figure 3).

\section{INTEGRATION OF THE CRAYFISH' IMMUNE COMPONENTS INTO FUNCTIONAL MECHANISMS}

\section{Role of Hemocyte Sub-populations in Mounting an Encapsulation}

A large parasite that cannot be phagocytosed nor engulfed by hemocytes triggers the recruitment of new hemocytes into the infection site to isolate the invader by what is known as encapsulation. Such a process is usually accompanied by the activation of the ProPO system and the formation of a melanin sheath around the pathogen, which should be digested by quinones resulting from $\mathrm{PO}$ cascading reactions. These aim to neutralize the pathogen and prevent it from disseminating the hemocel $(16,21,26,98)$. Overall, inflammation consists of several successive steps starting with the recognition step of pathogens and/or sensing tissue damages $(16,17,28,30)$, followed by the recruitment of immune cells to the infected/ damaged site, where additional effector molecules, such as clotting proteins (e.g., peroxinectins and transglutaminase), would be generated and released by these cells to consolidate pathogen isolation (i.e., capsule formation) $(4,14,26,84,85,88$, 92, 99, 100) (Figure 3). These activities may also initiate further recruitment of neo-formed hemocytes through the secretion of cytokine-like proteins (Astakine 1 and 2), which stimulate stem cell proliferation and new hemocyte maturation $(83,85)$. However, Persson et al. (14) demonstrated in an in vitro assessment that capsule formation is mainly assured by semigranular cells that are recruited and flattened to form aggregates around different spherules. Such capsules later develop into densely packed layers, which is not the case with granular cells forming less stable structures (4). In that same report, hyaline 
cells are described as the type that never participates in any aggregate formation (4). Other studies have reported that the hemocyte type involved in encapsulation depends on insect order (101). Dubovskiy et al. (101) stated that granular cells are the first to come in contact with and aggregate around the invader, therefore releasing clotting proteins to facilitate the termination of the process (101). In the same context, Jiravanichpaisal et al. (18) found that granular and semigranular cells in crayfish are cooperatively involved in encapsulation, whereas no functional involvement has been allocated to hyaline cells (Figure 1) (18, 30, 32, 102).

\section{Prospective Role of the Extracellular Trap Cell Death Pathway (ETosis) in Encapsulation}

Recent reports have highlighted the potential participation of HC in initiating encapsulation $(32,103)$. This finding has been demonstrated through the involvement of HC in implementing the extracellular trap cell death pathway (ETosis) in the crab Carcinus maenas $(104,105)$. In this context, it's worth highlighting that ETosis is a phenomenon which was first described in mammals and which can be triggered by inflammatory cells like neutrophils and other mammalian innate immune cells $(105,106)$. Such a phenomenon entails an extracellular expulsion of chromatin out of the nucleus intending to entrap and kill foreign invaders like bacteria, fungi, viruses, and parasites. ETosis requires the involvement and production of reactive oxygen species (ROS) through the NADPH oxidase enzyme complex and myeloperoxidase $(32,105)$. The inflammatory condition is described to favor the initiation of the process by de-condensing the nucleus within the cell and then expelling the cloud-like mesh of chromatin into the extracellular environment in a controlled manner (104, 105). Such material was found to be accompanied by antimicrobial agents (as antimicrobial peptides from granules and histones with antimicrobial functions as well) (107). ETosis has been recently found in some arthropods, bivalves, and cnidarians (103-105, 107). ETosis in the crab has been proved to be caused by the prohemocytes (homolog of HC in crayfish) (32, 103). Interestingly, SGC also seems to have the ability to release chromatin (103). Most importantly, ETosis greatly facilitates the encapsulation process through the entrapment of pathogens by expelled chromatin, and aids in assembling the flattened layers of hemocytes to form a sort of sheath around the foreign entity using the externalized chromatin as a scaffold during the early stage of encapsulation $(32,104,105)$. Peroxinectins and histones (mainly H2A) were also found to be greatly involved in the early stages of encapsulation $(103,105,107)$. The ETosis pathway needs to be investigated in crayfish to be confirmed as a potential immune strategy that could be assured or at least require to be initiated through the involvement of HC.

\section{Sessile Hemocytes-Potential Role in the Immune Response}

In contrast to circulating hemocytes in invertebrates, which are referred to as free wandering cells in the hemolymph, sessile hemocytes, also known as fixed phagocytes, are hemocytes that can migrate, infiltrate and inhabit different tissues and organs, due to the open circulatory system of invertebrates $(30,45,101$, $108,109)$. Therefore, sessile hemocytes can inhabit in, and sometimes even be fixed to, different tissues (e.g., as in the central channel of the gills, arterioles, and hepatopancreas) (18, 110). Recently, the involvement of such cells in determining a proper immune response has been extensively studied, raising a putative role in immune defenses $(108,109)$. Amongst others, sessile hemocytes have been described to be involved in phagocytic activities aiming to clear foreign materials and substances from the hemocoel, and to accumulate debris within their giant vacuoles in some organs like the gills, and from the epithelium of the hepatopancreas $(18,30,45,110)$. More interestingly, a potential role of replenishment for circulating hemocytes, following immune challenge, has been suggested as a putative strategy via a third route rather than hematopoiesis $(30,45)$. Otherwise, still to be confirmed as a role of sessile hemocytes is that of signal delivery following pathogen recognition (through PRRs). This assumption has been corroborated by the fact that fixed hemocytes have resulted from the circulating hemocytes' ability to migrate, attach and penetrate the basement membrane by extravasations into infection sites, even before the pathogen enters, as reviewed in Butt et al. (102). Recent studies have aimed at investigating the immune functions of sessile hemocytes from three different organs of Kuruma shrimp and have demonstrated the fact that such hemocytes differentially expressed immune-related genes compared to circulating hemocytes $(108,109)$. From the above, it's highly important to note the ability of "peripheral" hemocytes of the eastern oyster Crassostrea virginica (described as pallial hemocytes; compared to those designated as sessile hemocytes in crustaceans) to ensure exchanges with circulatory hemocytes $(111,112)$. Such exchanges have been described as bi-directional transepithelial migrations, which proved to regulate the pathogenesis of its obligate parasite Perkinsus marinus (111, 112). Interestingly, it has been demonstrated that such peripheral hemocytes share common general characteristics with circulating ones but also display some differences in their cell surface phenotypes (112-114). Overall, reporting the characteristics and role of sessile hemocytes in crayfish defense strategies would help in improving the understanding of the crayfish immune response.

\section{HYALINE CELLS AND NEOPLASIA- INTERFERENCE WITH THE IMMUNE RESPONSE}

Since the development of the hemocyte' classification system into sub-populations in crayfish, there has been much debate about the function of hyaline cells (HC), in spite of their very little shown phagocytic activity $(5,26,43,45,46,53,82)$. Recent studies have suggested that $\mathrm{HC}$ are in fact free wandering prohemocytes that might be released into circulation only under certain circumstances. This hypothesis has led to much 
debate about HC's identity, which is described as having hematopoietic cells' characteristics' (undifferentiated, expressing PCNA) $(43,45,47,76)$. This, in the light of the paradigm that clustering cell proliferation (excessive divisions), as can be exclusively occurs in the hematopoietic tissue, have strongly increased controversy over the identity of $\mathrm{HC}(32,46$, $52,53,85,103)$, could be explained by the possible triggering of a neoplastic disease (e.g., lymphoma-like disease or hemic neoplasia) (32, 43, 45). However, chronic inflammatory conditions like excessive release of Astakine1 (role of growth factor hormone), besides the recorded involvement of PDGVfactor within signaling processes, which may stimulate an angiogenesis profile, favoring appearance of neoplastic features $(83,115)$. It is worth noting that cells with peculiar shapes that mark the initiation of neoplasia and occurrence in crustaceans, have been already reported, which might be assumed as a potential process explaining the hemocytes' loss of immune capacity despite the recovery recorded in terms of number (i.e., increased THC after infections/challenges within different scenarios) (116).

Unfortunately, neoplasia in crayfish, and in crustaceans in general, hasn't been studied much. The scarcity of information on tumors in crustaceans has been attributed to the lack of accurate descriptions by experienced crustacean pathologists, and to the absence in most reported cases of histopathological examinations (116-119). Neoplastic features mostly exhibit nodules containing numerous anaplastic and hypertrophied/ giant cells, with either one large nucleus or several small nuclei. At the tissue level, possible tissue lesions presenting structural disorganization and high amounts of undifferentiated pleomorphic cells with hypertrophied nuclei and prominent nucleoli, in addition to bizarre multipolar mitotic figures have been reported (116-119). Despite the few documented case studies reporting crustacean neoplasia, a lack of accurate assessments has also been attributed to researchers' backgrounds, having only previously reported some cases of neoplasia in assessments that were primarily concerned with other topics.
In this same context, it's worth noting that studying the immune capacity of hemocytes should be considered while checking their expression of p53/63 and heat shock proteins (HSPs), such as HSP70 and HSP90, as biomarkers of neoplastic transformations.

\section{MOLECULAR COMPONENTS OF CRAYFISH IMMUNITY}

\section{Pattern Recognition Receptors (PRRs)}

So far it has been demonstrated that the activation of an effective, immune response requires the cooperative processing of molecular components in three mechanistic levels, which are the initiation process, response propagation through signal networking, and finally, the stimulation of effector molecules to neutralize pathogens (Figure 4).

However, the initiation step constitutes an accurate recognition of the pathogens or their associated cell walls (PAMPs like LPS and $\beta$-glucans) by the receptors of cells/ epithelium on the external surfaces, enriched with components of innate immunity (PRRs). Many PRRs have been identified so far in freshwater crayfish such as toll-like receptors, $\beta$-glucan binding proteins (LGBP), lectins, integrins, and Down syndrome cell adhesion molecules (Dscams). Fortunately, the TLRs are one of the well-conserved families of PRRs that perform a recognition role of diverse classes of pathogens including fungi, bacteria, and viruses. Several Toll receptors and related proteins have been identified in different freshwater crayfish, for example, Toll receptor 3 from A. astacus (120), PcToll1, 2, 3, 4, 5, and 6 from Procambarus clarkii (121-127). Crayfish PRRs represent lectins as an important class of molecules with a role of non-selfrecognition, however, lectins are proteins that bind to sugar using a characteristics carbohydrate recognition domain (CRD). In fact, among the 13 animal classes of lectins identified (according to their structural characteristics), crayfish lectins were reported to belong to at least three structural groups. Pc-Lec2 \& 3 from $P$. clarkii as C-type lectins $(126,128)$, PcL-lectin

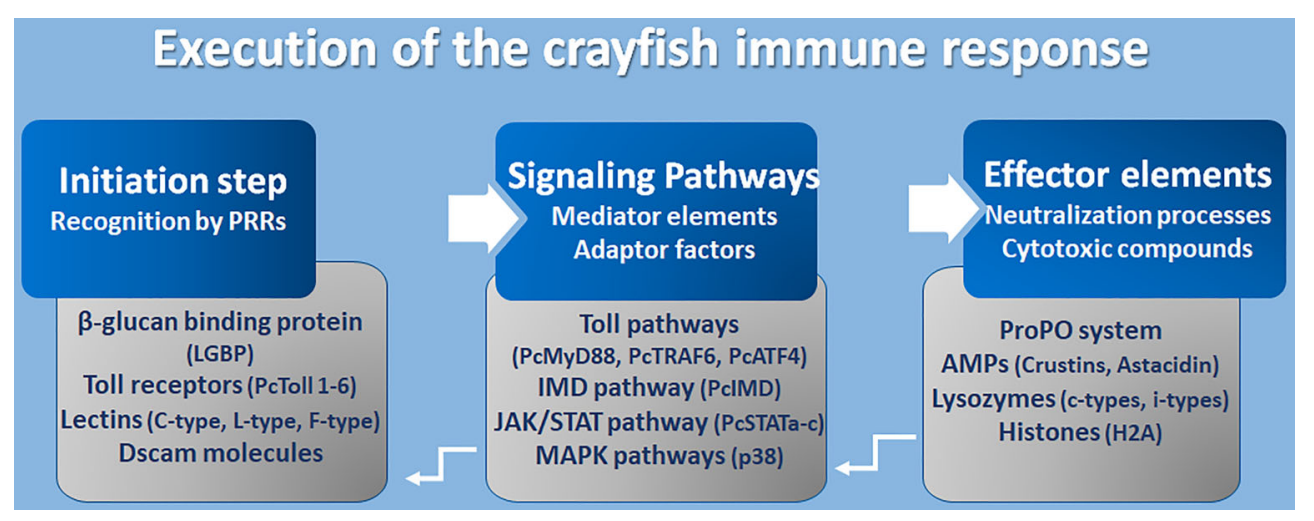

FIGURE 4 | Execution of crayfish immune response. Coordination of the immune response at molecular level (8, 16, 17, 97, 106, 120-141). 
from P. clarkii as L-type lectins (129), and PIFLP1 \& 2 from Pacifastacus leniusculus as Ficolin-like lectins (130). Because of their role in activating the ProPO system, LGBP are the most studied type of PRRs and have been identified to belong to the typical $\beta$-1,3-glucanase related protein (BGRP) family that participates in the recognition of a wide range of pathogens, including bacteria and fungi like the $A$. astaci, the causative agent of the plague disease in crayfish [further details are found in (126)]. Additionally, the Down syndrome cell adhesion molecules (Dscam), the largest Ig superfamily (IgSF) members, have been identified in arthropods including crustaceans (131). It's interesting to highlight that Dscam can produce thousands of isoforms (142). Dscam, presents membrane-bound and soluble forms (mDscam and sDscam), which are distinguished only by the presence/absence of transmembrane and cytoplasmic tail regions. Studies in the Chinese mitten crab Eriocheir sinensis, demonstrated that alternative splicing of Dscam can generate pathogen-specific isoforms with diverse epitopes in response to immune challenge, that potentially be able to recognize a broad spectrum of ligands. In fact, Li et al. (142) demonstrated that the mRNA and protein expressions of EsDscam were significantly upregulated after bacterial challenge, leading to produce isoforms found to bind specifically with the original bacteria to facilitate efficient clearance via phagocytosis by hemocytes. Li et al. (143) have elucidated that pathogen-induced particular soluble Dscam isoforms specifically binding with the original bacteria via epitope II, and then interact with membrane-bound Dscam that share the same extracellular regions via epitope I to promote phagocytosis. The cascading signal transduction mechanisms that activate post-Dscam binding pathogens remain not fully characterized. Dscams have been recorded in freshwater crayfish such as Cherax quadricarinatus and $P$. leniusculus, and have been proposed as key candidates for a somatically diversified receptor system speculated to be a hypervariable pattern-recognition receptor in crayfish immunity, playing the role of the cell surface receptor that triggers phagocytosis and opsonins due to the detection of soluble Dscam isoforms in crustacean hemolymphs $(131,132)$. Such findings have highlighted the putative involvement of Dscams as immunological effectors that promote immune memory through their ability to produce variable Ig domain combinations to promote the specificity of recognition and binding to a variety of pathogens through such splicing capacity $(126,144)$.

\section{Mediators and Signaling Adaptors}

A successful recognition step conducted by PRR members activates several downstream reactions aiming to propagate the immune response signals. Such networking is assured through a multitude of intermediate factors and mediator molecules of the Toll pathway, immune deficiency (IMD) pathway, Janus kinasesignal transducer activator of transcription (JAK/STAT) pathways, Mitogen-activated protein kinases (MAPKs) pathways, and the cytokines-like network. Many transcripts that have been assigned to the Toll pathways have been recorded for $A$. astacus (120). Up to now, many Toll intermediate homologs and signaling pathway components, such as those of the TLR4 signaling pathway (the cytosolic adaptor PcMyD88, tumor necrosis factor 6 (PcTRAF6), and PcATF4) have been identified in the red swamp crayfish $P$. clarkii $(124,133)$. However, some other key components which are necessary in TLR4 signaling, such as IRAK4, IRAK1, TRAF6, TAK1, and IRB, or their corresponding counterparts, remain unidentified in crustaceans (126). Besides, some other intermediate molecules belonging to other signaling pathways like the IMD pathway, the JAK/STAT and MAPK pathways, have been described in studies elucidating immunity against Gram-negative bacteria and triggering defenses through peptidoglycan (PG) receptors, and in response to white spot syndrome virus (WSSV) in P. clarkii $(117,126)$. The WSSV challenge modulates the PcIMD expression. The IMD pathway, which has a conserved function for regulating antimicrobial peptides' (AMP) expression in crayfish against Gram-negative bacteria, has also been reported to be involved in regulating the expression of crustins and lysozyme genes against WSSV (133). In addition, three different cDNA isoforms designated as PcSTATa, PcSTATb, and PcSTATc, belonging to the JAK/ STAT signaling pathway, have proved to play a crucial role against WSSV in the red swamp crayfish Procambarus clarkii by modulating the expression levels of anti-lipopolysaccharide factors (PcAlF1, PcAlF2, PcAlF3, PcAlF4, PcAlF5, and PcAlF6) and crustin (PcCrus1, PcCrus2, PcCrus3, and PcCrus4) (134). Furthermore, the involvement of p38MAPKinase, belonging to the serine/threonine protein kinases (MAPKs) (e.g., ERKs, JNKs, and p38s), in triggering the immune response in $P$. clarkii as results of exposure to cadmium has been demonstrated. As such, MAPKs could be irritated by various extracellular stimulations (e.g., inflammatory cytokines, pathogen infections, and environmental stress) (135).

\section{The Effector Elements of Immunity}

Immune components leading to the implementation of functional defenses against pathogens, like the ProPO system, and their related activation molecules such as serine proteases and proteases inhibitors, together with their intermediate regulators, have been thoroughly investigated $(8,24,136)$. The ProPO system activates the copper-containing enzyme phenoloxidase (PO) to oxidize phenols into quinones, which in turn are catalyzed into melanin. This process was found to be involved in wound healing and encapsulation as part of antifungal defenses [further details can be found in $(8,21,27)$ ].

AMPs are widely distributed small cationic polypeptides that exert an anti-pathogenic effect on a broad spectrum of pathogens. Crustacean AMPs can generally be classified into four groups according to their amino acid compositions and structural properties $(106,127)(1)$ : single-domain amphipathic linear $\alpha$-helical structure AMPs, including astacidins which are proline-rich peptides like astacidin 2 from $P$. leniusculus (137), and Pc-astacidin from P. clarkii (127) (2); single-domain peptides enriched with cysteine residues that are able to form at least one disulfide bridge between the B-sheets (3); AMPs with multi-domain linear $\alpha$-helical peptides enriched with certain amino acids, generally proline and/or glycine residues, including crustins, characterized by their acidic protein (WAP) domain at 
C-terminus, such as Pl-crustin $1 \& 2$ in P. leniusculus, and Pccrustin 4 in P. clarkii $(138,139)$, and procambarins, the glycinerich peptide described in $P$. clarkia (140); and (4) unconventional AMPs including proteins/protein-fragments with antimicrobial functions like H2A histones and anti-lipopolysaccharide factors (ALFs) (reviewed in 121, 126). Lastly, at least two types of invertebrate (i-types) lysozymes, Pclysi 1 and 2, have been identified in P. clarkii (141). However, all lysozyme types described in crustaceans are of the chicken type (C-type) (126). Lysozymes are important factors with antimicrobial functions defined by their muramidase activity, hydrolyzing $\beta$-1,4glycosidic linkage between $\mathrm{N}$-acetylmuramic acid and $\mathrm{N}$ acetylglucosamine, thus causing the lysis of peptidoglycan bacterial walls.

\section{FORWARD-LOOKING SUMMARY OF DEVELOPMENTS IN THE FIELD}

This review presents an extensive and up-to-date knowledge of crayfish immunity molecular components aiming to advance our understanding the defense mechanisms to evoke the old dilemma of plague disease, to enhance the resistance of endangered native European crayfishes. Unfortunately, early preventive strategies, like boosting crayfish immune responses, have not been fairly explored. Assessments of crayfish's immune responses should be considered in light of the recent updates on signaling pathways and processes that were found to be involved in different anti-pathogenic defenses. It is also interesting to highlight what is described as host-pathogen interactions as an underlying factor influencing the adjustment of an effective immune response. However, a recent study conducted by Zheng et al. (145) demonstrated the involvement of the Toll pathways in the early detection of fungal infection, even before the pathogen penetrates the host cuticle. The Locusta migratoria manilensis can activate the Toll signaling pathway by upregulating the Spaetzle and Cactus members of the upstream PRRs of the Toll pathway following a challenge by $\beta$-1, 3-glucan (laminarin) from the cell wall of the fungus Metarhizium acridum when applied onto the host cuticle, even before fungal penetration (145). Such findings pave the way for further investigations taking into account the already described different signaling pathways in crayfish to increase our understanding of host-pathogen interactions in resolving the

\section{REFERENCES}

1. Jussila J, Makkonen J, Vainikka A, Kortet R, Kokko H. Latent Crayfish Plague (Aphanomyces astaci) Infection in a Robust Wild Noble Cray Fish (Astacus astacus) Population. Aquaculture (2011) 321(1-2):17-20. doi: 10.1016/j.aquaculture.2011.08.026

2. Makkonen J, Jussila J, Kokko H. The Diversity of the Pathogenic Oomycete (Aphanomyces astaci) Chitinase Genes Within the Genotypes Indicate Adaptation to its Hosts. Fungal Genet Biol (2012) 49(8):635-42. doi: 10.1016/j.fgb.2012.05.014

3. Makkonen J, Kokko H, Vainikka A, Kortet R, Jussila J. Dose-Dependent Mortality of the Noble Crayfish (Astacus astacus) to Different Strains of the dilemma of crayfish plague disease. Yet, this aim could be more widen with integrative assessments taking into account the integration of the immune components into functional mechanisms. In doing so, understanding the importance of cellular versus humoral defenses in crayfish immune response is timely needed. This implies that greater emphasis needs to be placed on understanding the molecular mechanisms underlying cellular involvement in innate immune defenses of susceptible crayfish species. Such, may constitute a basis for wider assessments to overcome current limitations in forming immune priming strategies against $A$. astaci and to enhance conservation efforts of the endangered species. In this context, prospective acquirement of a specific immune response, named immunological memory of innate immunity, has been evidenced in many invertebrates, including crustaceans. However, deciphering the mechanisms of such memory is yet to be fully investigated. The main proposed underpinning molecular mechanistic is epigenetic re-programming or modification on gene expression due to different factors other than DNA mutations, which also remain elusive. To this end, an overreaching goal aiming to survey the modifications in the molecular mechanisms underlying the immunity of European freshwater crayfish, by exploring a potential transgenerational transfer of resistance traits against $A$. astaci, may consolidate breeding programs and crayfish production in captivity, thus enhancing European crayfish conservation.

\section{AUTHOR CONTRIBUTIONS}

The author confirms being the sole contributor of this work and has approved it for publication.

\section{ACKNOWLEDGMENTS}

The author would like to thank Prof. Irene Söderhäll (Invertebrate infection biology Lab, Department of Organismal Biology, Uppsala University, Sweden) for her time and consideration to review this manuscript and for her valuable recommendations and assistance during the editing of this paper. The author also thanks Mrs. Nayua Abdelkefi Zorrilla for the proofreading and editing the English language of the manuscript.

Crayfish Plague (Aphanomyces astaci). J Invertebrate Pathol (2014) 115:8691. doi: 10.1016/j.jip.2013.10.009

4. Persson M, Cerenius L, Söderhäll K. The Influence of Haemocyte Number on the Resistance of the Freshwater Crayfish, Pacifastacus leniusculus dana, to the Parasitic Fungus Aphanomyces astaci. J Fish Dis (1987) 10(6):471-7. doi: 10.1111/j.1365-2761.1987.tb01098.x

5. Cerenius L, Bangyeekhun E, Keyser P, Söderhäll I, Söderhäll K. Host Prophenoloxidase Expression in Freshwater Crayfish is Linked to Increased Resistance to the Crayfish Plague Fungus, Aphanomyces astaci. Cell Microbiol (2003) 5:353-7. doi: 10.1046/j.1462-5822.2003.00282.x

6. Edgerton BF, Henttonen P, Jussila J, Mannonen A, Paasonen P, Taugbol $\mathrm{T}$, et al. Understanding the Causes of Disease in European 
Freshwater Crayfish. Conserv Biol (2004) 18:1466-74. doi: 10.1111/j.15231739.2004.00436.x

7. Nyhlèn L, Unestam T. Wound Reactions and Aphanomyces Crayfish Cuticle Astaci Growth in. J Invertebrate Pathol (1980) 197:187-97. doi: 10.1016/0022-2011(80)90023-3

8. Cerenius L, Andersson MG, Söderhäll K. Aphanomyces astaci and Crustaceans Oomycete Genetics and Genomics: Diversity, Interactions, and Research Tools. K Lamour, S Kamoun, editors. United States: John Wiley \& Sons, Inc (2008) p. 425-33. doi: 10.1002/9780470475898.ch21

9. Longshaw M. Diseases of Crayfish: A Review. J Invertebrate Pathol (2011) 106(1):54-70. doi: 10.1016/j.jip.2010.09.013

10. Gruber C, Kortet R, Vainikka A, Hyvärinen P, Rantala MJ, Pikkarainen A, et al. Variation in Resistance to the Invasive Crayfish Plague and Immune Defence in the Native Noble Crayfish. Annales Zoologici Fennici (2014) 51 (4):371-89. doi: 10.5735/086.051.0403

11. Svoboda J, Mrugała A, Kozubíková-Balcarová A, Petrusek A. Hosts and Transmission of the Crayfish Plague Pathogen Aphanomyces astaci: A Review. J Fish Dis (2017) 40(1):127-40. doi: 10.1111/jfd.12472

12. Oidtmann B, Heitzl E, Rogers D, Hoffmann RW. Transmission of Crayfish Plague. Dis Aquat Organisms (2002) 52(2):159-67. doi: 10.3354/dao052159

13. Smith VJ, Ratcliffe NA. Host Defence Reactions of the Shore Crab, Carcinus maenas (L.), In Vitro. J Marine Biol Assoc United Kingdom (1978) 58(2):36779. doi: 10.1017/S0025315400028046

14. Persson M, Vey A, Söderhäll K. Encapsulation of Foreign Particles In Vitro by Separated Blood Cells From Crayfish, Astacus Leptodactylus. Cell Tissue Res (1987) 247(2):409-15. doi: 10.1007/BF00218322

15. Johansson MW, Söderhäll K. Cellular Immunity in Crustaceans and the proPO System. Parasitol Today (1989) 5(6):171-6. doi: 10.1016/0169-4758 (89)90139-7

16. Cerenius L, Söderhäll K. The Prophenoloxidase-Activating System in Invertebrates. Immunol Rev (2004) 198:116-26. doi: 10.1111/j.01052896.2004.00116.x

17. Cerenius L, Söderhäll K. Crayfish Immunity - Recent Findings. Dev Comp Immunol (2018) 80:94-8. doi: 10.1016/j.dci.2017.05.010

18. Jiravanichpaisal P, Lee BL, Söderhäll K. Cell-Mediated Immunity in Arthropods: Hematopoiesis, Coagulation, Melanization and Opsonization. Immunobiology (2006) 211(4):213-36. doi: 10.1016/j.imbio.2005.10.015

19. Kan H, Kim CH, Kwon HM, Park JW, Roh KB, Lee H, et al. Molecular Control of Phenoloxidase-Induced Melanin Synthesis in an Insect. J Biol Chem (2008) 283(37):25316-23. doi: 10.1074/jbc.M804364200

20. Roh KB, Kim C-H, Lee H, Kwon H-M, Park J-W, Ryu J-H, et al. Proteolytic Cascade for the Activation of the Insect Toll Pathway Induced by the Fungal Cell Wall Component. J Biol Chem (2009) 284(29):19474-81. doi: 10.1074/ jbc.m109.007419

21. Cerenius L, Kawabata S-i, Lee BL, Nonaka M, Söderhäll K. Proteolytic Cascades and Their Involvement in Invertebrate Immunity. Trends Biochem Sci (2010) 35(10):575-83. doi: 10.1016/j.tibs.2010.04.006

22. Söderhäll K, Wingren A, Johansson MW, Bertheussen K. The Cytotoxic Reaction of Hemocytes From the Freshwater Crayfish, Astacus astacus. Cell Immunol (1985) 94(2):326-32. doi: 10.1016/0008-8749(85)90256-4

23. Söderhäll K, Smith VJ, Johansson MW. Exocytosis and Uptake of Bacteria by Isolated Haemocyte Populations of Two Crustaceans: Evidence for Cellular Co-Operation in the Defence Reactions of Arthropods. Cell Tissue Res (1986) 245(1):43-9. doi: 10.1007/BF00218085

24. Kobayashi M, Johansson MW, Söderhäll K. The 76 Kd Cell-Adhesion Factor From Crayfish Haemocytes Promotes Encapsulation In Vitro. Cell Tissue Res (1990) 260(1):13-8. doi: 10.1007/BF00297485

25. Jiravanichpaisal P, Söderhäll K, Söderhäll I. Inflammation in Arthropods. Curr Pharm Design (2011) 16(38):4166-74. doi: 10.2174/1381612 10794519165

26. Smith VJ, Söderhäll K. Induction of Degranulation and Lysis of Haemocytes in the Freshwater Crayfish, Astacus astacus by Components of the Prophenoloxidase Activating System In Vitro. Cell Tissue Res (1983) 233 (2):295-303. doi: 10.1007/BF00238297

27. Cerenius L, Lee BL, Söderhäll K. The proPO-system: Pros and Cons for its Role in Invertebrate Immunity. Trends Immunol (2008) 26(6):263-71. doi: $10.1016 /$ j.it.2008.02.009
28. Cerenius L, Söderhäll K. Arthropoda: Pattern Recognition Proteins in Crustacean Immunity. In: EL Cooper, editor. Advances in Comparative Immunology. Cham: Springer (2018). p. 213-24. doi: 10.1007/978-3-319-76768-0

29. Lin X, Kim YA, Lee BL, Söderhäll K, Söderhäll I. Identification and Properties of a Receptor for the Invertebrate Cytokine Astakine, Involved in Hematopoiesis. Exp Cell Res (2009) 315(7):1171-80. doi: 10.1016/ j.yexcr.2009.01.001

30. Rowley AF. The Immune System of Crustaceans, Encyclopedia of Immunobiology. Amsterdam, Netherlands: Elsevier (2016). doi: 10.1016/ B978-0-12-374279-7.12005-3

31. Liu H, Söderhäll K, Jiravanichpaisal P. Antiviral Immunity in Crustaceans. Fish Shellfish Immunol (2009) 27(2):79-88. doi: 10.1016/j.fsi.2009.02.009

32. Smith VJ. Immunology of Invertebrates: Cellular. Els. Chichester, UK: John Wiley \& Sons, Ltd (2016) p. 1-13. doi: 10.1002/9780470015902. a0002344.pub3

33. Jussila J, Vainikka A, Kortet R, Kokko H. Crayfish Plague Dilemma: How to be a Courteous Killer? Boreal Environ Res (2014) 19(3):235-44.

34. Martín-Torrijos L, Campos Llach M, Pou-Rovira Q, Diéguez-Uribeondo J. Resistance to the Crayfish Plague, Aphanomyces astaci (Oomycota) in the Endangered Freshwater Crayfish Species, Austropotamobius Pallipes. PloS One (2017) 12(7):1-13. doi: 10.1371/journal.pone.0181226

35. Panteleit J, Keller NS, Diéguez-Uribeondo J, Makkonen J, Martín-Torrijos L, Patrulea V, et al. Hidden Sites in the Distribution of the Crayfish Plague Pathogen Aphanomyces astaci in Eastern Europe: Relicts of Genetic Groups From Older Outbreaks? J Invertebrate Pathol (2018) 157:117-24. doi: 10.1016/j.jip.2018.05.006

36. Becking T, Mrugała A, Delaunay C, Svoboda J, Raimond M, Viljamaa-Dirks S, et al. Effect of Experimental Exposure to Differently Virulent Aphanomyces astaci Strains on the Immune Response of the Noble Crayfish Astacus astacus. J Invertebrate Pathol (2015) 132:115-24. doi: 10.1016/j.jip.2015.08.007

37. Svoboda J, Mrugała A, Kozubíková-Balcarová E, Kouba A, DiéguezUribeondoc J, Petrusek A, et al. Resistance to the Crayfish Plague Pathogen, Aphanomyces astaci, in Two Freshwater Shrimps. J Invertebrate Pathol (2014) 121:97-104. doi: 10.1016/j.jip.2014.07.004

38. Filipova L, Petrusek A, Matasova K, Delaunay C, Grandjean F. Prevalence of the Crayfish Plague Pathogen Aphanomyces astaci in Populations of the Signal Crayfish Pacifastacus leniusculus in France: Evaluating the Threat to Native Crayfish. PloS One (2013) 8:e70157. doi: 10.1371/ journal.pone.0070157

39. Alderman DJ. Geographical Spread of Bacterial and Fungal Diseases of Crustaceans. Rev Scientifique Et Technique l'Office Int Des Epizooties (1996) 15:603-32. doi: 10.20506/rst.15.2.943

40. Martín-Torrijos L, Kawai T, Makkonen J, Jussila J, Kokko H, DiéguezUribeondo J. Crayfish Plague in Japan: A Real Threat to the Endemic Cambaroides Japonicus. PloS One (2018) 13(4):e0195353. doi: 10.1371/ journal.pone. 0195353

41. Schrimpf A, Schmidt T, Schulz R. Invasive Chinese Mitten Crab (Eriocheir Sinensis) Transmits Crayfish Plague Pathogen (Aphanomyces astaci). Aquat Invasions (2014) 9:203-9. doi: 10.3391/ai.2014.9.2.09

42. Ratcliffe NA, Rowley AF, Fitzgerald SW, Rhodes CP. Invertebrate Immunity: Basic Concepts and Recent Advances. Int Rev Cytology (1985) 97(C):183350. doi: 10.1016/S0074-7696(08)62351-7

43. Giulianini PG, Bierti M, Lorenzon S, Battistella S, Ferrero EA Ultrastructural and Functional Characterization of Circulating Hemocytes From the Freshwater Crayfish Astacus Leptodactylus: Cell Types and Their Role After In Vivo Artificial non-Self-Challenge. Micron (2007) 38(1):49-57. doi: 10.1016/j.micron.2006.03.019

44. Giglio A, Manfrin C, Zanetti M, Aquiloni L, Simeon E, Bravin MK, et al Effects of X-ray Irradiation on Haemocytes of Procambarus clarkii (Arthropoda: Decapoda) Males. Eur Zoological J (2018) 85(1):26-35. doi: 10.1080/24750263.2017.1423119

45. Li F, Chang X, Xua L, Yang F. Different Roles of Crayfish Hemocytes in the Uptake of Foreign Particles. Fish Shellfish Immunol (2018) 77:112-9. doi: 10.1016/j.fsi.2018.03.029

46. Wu C, Söderhäll I, Kim YA, Liu H, Söderhäll K. Hemocyte-Lineage Marker Proteins in a Crustacean, the Freshwater Crayfish, Pacifastacus leniusculus. Proteomics (2008) 8(20):4226-35. doi: 10.1002/pmic.200800177 
47. Söderhäll I. Crustacean Hematopoiesis. Dev Comp Immunol (2016) 58:12941. doi: $10.1016 /$ j.dci.2015.12.009

48. Mix MC, Sparks AK. Hemocyte Classification and Differential Counts in the Dungeness Crab, Cancer Magister. J Invertebrate Pathol (1980) 35(2):13443. doi: 10.1016/0022-2011(80)90176-7

49. Söderhäll K, Smith VJ. Separation of the Haemocyte Populations of Carcinus maenas and Other Marine Decapods, and Prophenoloxidase Distribution. Dev Comp Immunol (1983) 7:229-39. doi: 10.1016/0145-305x(83)90004-6

50. Ding Z, Du J, Ou J, Li W, Wu T, Xiu Y, et al. Classification of Circulating Hemocytes From the Red Swamp Crayfish Procambarus clarkii and Their Susceptibility to the Novel Pathogen Spiroplasma Eriocheiris In Vitro. Aquaculture (2012) 356-357:371-80. doi: 10.1016/j.aquaculture.2012.04.042

51. Lv S, Xu J, Zhao J, Yin N, Lu B, Li S, et al. Classification and Phagocytosis of Circulating Haemocytes in Chinese Mitten Crab (Eriocheir Sinensis) and the Effect of Extrinsic Stimulation on Circulating Haemocytes In Vivo. Fish Shellfish Immunol (2014) 9(2):415-22. doi: 10.1016/j.fsi.2014.05.036

52. Hammond JA, Smith VJ. Lipopolysaccharide Induces DNA-synthesis in a Sub-Population of Hemocytes From the Swimming Crab, Liocarcinus Depurator. Dev Comp Immunol (2002) 26(3):227-36. doi: 10.1016/s0145$305 \times(01) 00069-6$

53. Söderhäll I, Bangyeekhun E, Mayo S, Söderhäll K. Hemocyte Production and Maturation in an Invertebrate Animal; Proliferation and Gene Expression in Hematopoietic Stem Cells of Pacifastacus leniusculus. Dev Comp Immunol (2003) 27(8):661-72. doi: 10.1016/S0145-305X(03)00039-9

54. Cerenius L, Kawabata Sc, Soöerhäll K. Biological and Immunological Aspects of Innate Defence Mechanisms Activated by $(1,3) \beta$-Glucans and Related Polysaccharides in Invertebrates. In: Chemistry, Biochemistry, and Biology of 1-3 Beta Glucans and Related Polysaccharides. Cambridge, Massachusetts, United States: Elsevier Inc. Academic press (2009). p. 563-77. doi: 10.1016/B978-0-12-373971-1.00017-0

55. Smith VJ, Ratcliffe NA. Pathological Changes in the Nephrocytes of the Shore Crab, Carcinus maenas, Following Injection of Bacteria. J Invertebrate Pathol (1981) 38(1):113-21. doi: 10.1016/0022-2011(81)90041-0

56. Powell A, Rowley AF. Tissue Changes in the Shore Crab Carcinus maenas as a Result of Infection by the Parasitic Barnacle Sacculina Carcini. Dis Aquat Organisms (2008) 80(1):75-9. doi: 10.3354/dao01930

57. Edgerton BF, Owens L. Histopathological Surveys of the Redclaw Freshwater Crayfish, Cherax quadricarinatus, in Australia. Aquaculture (1999) 180(12):23-40. doi: 10.1016/S0044-8486(99)00195-7

58. Stentiford GD, Feist SW. A Histopathological Survey of Shore Crab (Carcinus maenas) and Brown Shrimp (Crangon Crangon) From Six Estuaries in the United Kingdom. J Invertebrate Pathol (2005) 88(2):13646. doi: 10.1016/j.jip.2005.01.006

59. Sharshar KM. Histopathological and Pcr Diagnostc Techniques for Detection of White Spot Syndrome Virus in Different Tissues of Procambarus clarkii -. Egyptian J Exp Biol (Zoology) (2008) 4(0):307-16.

60. Jiravanichpaisal P, Roos S, Edsman L, Liu L, Söderhäll K. A Highly Virulent Pathogen, Aeromonas Hydrophila, From the Freshwater Crayfish Pacifastacus leniusculus. J Invertebrate Pathol (2009) 101(1):56-66. doi: 10.1016/j.jip.2009.02.002

61. Wei K, Yang J. Oxidative Damage of Hepatopancreas Induced by Pollutiondepresses Humoral Immunity Response in the Freshwater Crayfish Procambarus clarkii. Fish Shellfish Immunol (2015) 43(2):510-9. doi: $10.1016 /$ j.fsi.2015.01.013

62. Wei KQ, Yang JX. Histological Alterations and Immune Response in the Crayfish Procambarus clarkii Given rVP28-incorporated Diets. Fish Shellfish Immunol (2011) 31(6):1122-8. doi: 10.1016/j.fsi.2011.10.002

63. Ding Z, Yao W, Du J, Ren Q, Li W, Wu T, et al. Histopathological Characterization and in Situ Hybridization of a Novel Spiroplasma Pathogen in the Freshwater Crayfish Procambarus clarkii. Aquaculture (2013) 380-383:106-13. doi: 10.1016/j.aquaculture.2012.12.007

64. Wren M, Gagnon ZE. A Histopathological Study of Hudson River Crayfish, Orconectes virilis, Exposed to Platinum Group Metals. J Environ Sci Health Part A Toxic/Hazardous Substances Environ Eng (2014) 49(2):135-45. doi: $10.1080 / 10934529.2013 .838836$

65. Samnejhad A, Afsharnasab M, Kakoolaki S, Sepahdari A. Effect of Aeromonas Hydrophila Infection With High and Normal Water Temperature on Total Hemocyte Count, Total Plasma Protein and
Histopathological Differences in Freshwater Crayfish Astacus Leptodactylus. Survey Fisheries Sci (2016) 2(2):45-65. doi: 10.18331/ sfs2016.2.2.4

66. Silva MAS, Almeida Neto ME, Ramiro BO, Santos ITF, Guerra RR. Histomorphologic Characterization of the Hepatopancreas of Freshwater Prawn Macrobrachium rosenbergii (De Man, 1879). Arquivo Brasileiro Medicina Veterinaria e Zootecnia (2018) 70(5):1539-46. doi: 10.1590/ 1678-4162-10497

67. Bernet D, Schmidt H, Meier W, Burkhardt-Holm P, Wahli T. Histopathology in Fish: Proposal for a Protocol to Assess Aquatic Pollution. J Fish Dis (1999) 22(1):25-34. doi: 10.1046/j.13652761.1999.00134.x

68. Costa PM, Diniz MS, Caeiro S, Lobo J, Martins M, Ferreira AM, et al. Histological Biomarkers in Liver and Gills of Juvenile Solea Senegalensis Exposed to Contaminated Estuarine Sediments: A Weighted Indices Approach. Aquat Toxicol (2009) 92(3):202-12. doi: 10.1016/ j.aquatox.2008.12.009

69. Bouallegui Y, Ben-Younes R, Bellamine H, Oueslati R. Histopathology and Analyses of Inflammation Intensity in the Gills of Mussels Exposed to Silver Nanoparticles: Role of Nanoparticle Size, Exposure Time, and Uptake Pathways. Toxicol Mech Methods (2017) 27(8):582-91. doi: 10.1080/ 15376516.2017.1337258

70. Bouallegui Y, Ben-Younes R, Bellamine H, Oueslati R. Histopathological Indices and Inflammatory Response in the Digestive Gland of the Mussel Mytilus Galloprovincialis as Biomarker of Immunotoxicity to Silver Nanoparticles. Biomarkers (2018) 23(3):277-87. doi: 10.1080/ 1354750X.2017.1409803

71. Stara A, Kouba A, Velisek J. Biochemical and Histological Effects of SubChronic Exposure to Atrazine in Crayfish Cherax Destructor. Chemico Biological Interact (2018) 291(June):95-102. doi: 10.1016/j.cbi.2018.06.012

72. Lanz H, Tsutsumi V, Aréchiga H. Morphological and Biochemical Characterization of Procambarus clarki Blood Cells. Dev Comp Immunol (1993) 17:389-97. doi: 10.1016/0145-305X(93)90030-T

73. Matozzo V, Marin MG. The Role of Haemocytes From the Crab Carcinus Aestuarii (Crustacea, Decapoda) in Immune Responses: A First Survey. Fish Shellfish Immunol (2010) 28(4):534-41. doi: 10.1016/j.fsi.2009.12.003

74. Matozzo V, Mrin MG. First Cytochemical Study of Haemocytes From the Crab Carcinus a Estuarii (Crustacea, Decapoda). Eur J Histochem (2010) 54 (1):44-9. doi: 10.4081/ejh.2010.e9

75. Lin X, Söderhäll I. Crustacean Hematopoiesis and the Astakine Cytokines. Blood (2011) 117(24):6417-24. doi: 10.1182/blood-2010-11-320614

76. Söderhäll I, Junkunlo K. A Comparative Global Proteomic Analysis of the Hematopoietic Lineages in the Crustacean Pacifastacus leniusculus. Dev Comp Immunol (2019) 92:170-8. doi: 10.1016/j.dci.2018.11.016

77. Junkunlo K, Söderhäll K, Söderhäll I. Transglutaminase 1 and 2 are Localized in Different Blood Cells in the Freshwater Crayfish Pacifastacus leniusculus. Fish Shellfish Immunol (2020) 104:83-91. doi: 10.1016/ j.fsi.2020.05.062

78. Fu Y, Huang X, Zhang P, Van de Leemput J, Han Z. Single-Cell RNA Sequencing Identifies Novel Cell Types in Drosophila Blood. J Genet Genomics (2020) 47:175-86. doi: 10.1016/j.jgg.2020.02.004

79. Tattikota SG, Cho B, Liu Y, Hu Y, Barrera V, Steinbaugh MJ, et al. A SingleCell Survey of Drosophila Blood. eLife (2020) 9:e54818. doi: 10.7554/ eLife.54818

80. van de Braak CB, Botterblom MH, Liu W, Taverne N, van der Knaap WP, Rombout JH. The Role of the Haematopoietic Tissue in Haemocyte Production and Maturation in the Black Tiger Shrimp (Penaeus monodon). Fish Shellfish Immunol (2002) 12(3):253-72. doi: 10.1006/ fsim. 2001.0369

81. Lin X, Soderhall K, Soderhall I. Invertebrate Hematopoiesis: An AstakineDependent Novel Hematopoietic Factor. J Immunol (2011) 186(4):2073-9. doi: 10.4049/jimmunol.1001229

82. Johansson MW, Keyser P, Sritunyalucksana K, Söderhäll K. Crustacean Haemocytes and Haematopoiesis. Aquaculture (2000) 191(1-3):45-52. doi: $10.1016 /$ S0044-8486(00)00418-X

83. Lin X, Novotny M, Söderhäll K, Söderhäll I. Ancient Cytokines, the Role of Astakines as Hematopoietic Growth Factors. J Biol Chem (2010) 285 (37):28577-86. doi: 10.1074/jbc.M110.138560 
84. Junkunlo K, Söderhäll K, Söderhäll I. Clotting Protein - An Extracellular Matrix (ECM) Protein Involved in Crustacean Hematopoiesis. Dev Comp Immunol (2018) 78:132-40. doi: 10.1016/j.dci.2017.09.017

85. Söderhäll I, Kim Y-A, Jiravanichpaisal P, Lee S-Y, Söderhäll K. An Ancient Role for a Prokineticin Domain in Invertebrate Hematopoiesis. J Immunol (2005) 174(10):6153-60. doi: 10.4049/jimmunol.174.10.6153

86. Lin X, Söderhäll K, Söderhäll I. Transglutaminase Activity in the Hematopoietic Tissue of a Crustacean, Pacifastacus leniusculus, Importance in Hemocyte Homeostasis. BMC Immunol (2008) 9:1-11. doi: 10.1186/1471-2172-9-58

87. Junkunlo K, Söderhäll K, Söderhäll I, Noonin C. Reactive Oxygen Species Affect Transglutaminase Activity and Regulate Hematopoiesis in a Crustacean. J Biol Chem (2016) 291(34):17593-601. doi: 10.1074/ jbc.M116.741348

88. Sirikharin R, Junkunlo K, Söderhäll K, Söderhäll I. Role of Astakine1 in Regulating Transglutaminase Activity. Dev Comp Immunol (2017) 76:77-82. doi: 10.1016/j.dci.2017.05.015

89. Ericsson L, Irene S. Astakines in Arthropods E Phylogeny and Gene Structure. Dev Comp Immunol (2018) 81:141-51. doi: 10.1016/j.dci.2017.11.005

90. Junkunlo K, Söderhäll K, Söderhäll I. Transglutaminase Inhibition Stimulates Hematopoiesis and Reduces Aggressive Behavior of Crayfish, Pacifastacus leniusculus. J Biol Chem (2019) 294(2):708-15. doi: 10.1074/ jbc.RA118.005489

91. Chen M-Y, Hu K-Y, Huang C-C, Song Y-L. More Than One Type of Transglutaminase in Invertebrates? A Second Type of Transglutaminase is Involved in Shrimp Coagulation. Dev Comp Immunol (2005) 29:1003-16. doi: 10.1016/j.dci.2005.03.012

92. Cerenius L, Söderhäll K. Coagulation in Invertebrates. J Innate Immun (2011) 3:3-8. doi: 10.1159/000322066

93. Beltz BS, Zhang Y, Benton JL, Sandeman DC. Adult Neurogenesis in the Decapod Crustacean Brain: A Hematopoietic Connection? Eur J Neurosci (2011) 34:870-83. doi: 10.1111/j.1460-9568.2011.07802.x

94. Benton JL, Kery R, Li J, Noonin C, Söderhäll I, Beltz BS. Cells From the Immune System Generate Adult-Born Neurons in Crayfish. Dev Cell (2014) 30(3):322-33. doi: 10.1016/j.devcel.2014.06.016

95. Noonin C. Involvement of Serotonin in Crayfish Hematopoiesis. Dev Comp Immunol (2018) 86:189-95. doi: 10.1016/j.dci.2018.05.006

96. Saelee N, Noonin C, Nupan B, Junkunlo K, Phongdara A, Lin X, et al. B -Thymosins and Hemocyte Homeostasis in a Crustacean. PloS One (2013) 8 (4):e60974. doi: 10.1371/journal.pone.0060974

97. Chang YT, Lin CY, Tsai CY, Siva VS, Chu CY, Tsai HJ, et al. The New Face of the Old Molecules: Crustin Pm4 and Transglutaminase Type I Serving as RNPs Down-Regulate Astakine-Mediated Hematopoiesis. PLoS ONE (2013) 8(8):e72793. doi: 10.1371/journal.pone.0072793

98. Liu H, Jiravanichpaisal P, Cerenius L, Lee BL, Söderhäll I, Söderhäll K. Phenoloxidase is an Important Component of the Defense Against Aeromonas Hydrophila Infection in a Crustacean, Pacifastacus leniusculus. J Biol Chem (2007) 282(46):33593-8. doi: 10.1074/jbc.M706113200

99. Hall M, Wang R, van Antwerpen R, Sottrup-Jensen L, Söderhäll K. The Crayfish Plasma Clotting Protein: A Vitellogenin-Related Protein Responsible for Clot Formation in Crustacean Blood. Proc Natl Acad Sci USA (1999) 96(5):1965-70. doi: 10.1073/pnas.96.5.1965

100. Ang RW, Iang ZL, All MH. A Transglutaminase Involved in the Coagulation System of the Freshwater Crayfish, Pacifastacus leniusculus. Tissue Localisation and cDNA Cloning. Fish Shellfish Immunol (2001) 11(7):62337. doi: 10.1006/fsim.2001.0341

101. Dubovskiy IM, Kryukova NA, Glupov VV, Ratcliffe NA. 'Encapsulation and Nodulation in Insects. Invertebrates Survival J (2016) 13:229-46. doi: 10.25431/1824-307X/isj.v13i1.229-246

102. Butt TM, Coates CJ, Dubovskiy IM, Ratcliffe NA. Entomopathogenic Fungi: New Insights Into Host-Pathogen Interactions. Adv Genet (2016) 94:307-64. doi: 10.1016/bs.adgen.2016.01.006

103. Robb CT, Dyrynda EA, Gray RD, Rossi AG, Smith VJ. Invertebrate Extracellular Phagocyte Traps Show That Chromatin is an Ancient Defence Weapon. Nat Commun (2014) 5:1-11. doi: 10.1038/ncomms5627

104. Brinkmann V, Reichard U, Goosmann C, Fauler B, Uhlemann Y, Weiss DS, et al. Neutrophil Extracellular Traps Kill Bacteria. Science (2004) 303 (5663):1532-5. doi: 10.1126/science.1092385
105. Brinkmann V, Zychlinsky A. Neutrophil Extracellular Traps: Is Immunity the Second Function of Chromatin? J Cell Biol (2012) 198(5):773-83. doi: $10.1083 /$ jcb. 201203170

106. Rosa RD, Barracco MA. Antimicrobial Peptides in Crustaceans. Invertebrate Survival J (2010) 7(2):262-84.

107. Poirier AC, Schmitt P, Rosa RD, Vanhove AS, Kieffer-Jaquinod S, Rubio TP, et al. Antimicrobial Histones and DNA Traps in Invertebrate: Evidences in Crassostrea gigas. J Biol Chem (2014) 289(36):24821-31. doi: 10.1074/ jbc.M114.576546

108. Koiwai K, Kondo H, Hirono I. The Immune Functions of Sessile Hemocytes in Three Organs of Kuruma Shrimp Marsupenaeus Japonicus Differ From Those of Circulating Hemocytes. Fish Shellfish Immunol (2018) 78:109-13. doi: $10.1016 /$ j.fsi.2018.04.036

109. Koiwai K, Kondo H, Hirono I. Isolation and Molecular Characterization of Hemocyte Sub - Populations in Kuruma Shrimp Marsupenaeus japonicus. Fisheries Sci (2019) 85:521-32. doi: 10.1007/s12562-019-01311-5

110. Cerenius L, Soderhall K. Crustacean Immune Responses and Their Implications for Disease Control, Infectious Disease. In: B Austin, editor. Aquaculture: Prevention and Control. Cambridge, UK: Sawston, Woodhead Publishing Series in Food Science, Technology and Nutrition (2012). doi: 10.1016/B978-0-85709-016-4.50002-7

111. Lau YT, Gambino L, Santos B, Pales Espinosa E, Allam B. Regulation of Oyster (Crassostrea virginica) Hemocyte Motility by the Intracellular Parasite Perkinsus marinus: A Possible Mechanism for Host Infection. Fish Shellfish Immunol (2018) 78:18-25. doi: 10.1016/j.fsi.2018.04.019

112. Lau YT, Gambino L, Santos B, Pales Espinosa E, Allam B. Transepithelial Migration of Mucosal Hemocytes in Crassostrea virginica and Potential Role in Perkinsus Marinus Pathogenesis. J Invertebrate Pathol (2018) 153:122-9. doi: 10.1016/j.jip.2018.03.004

113. Pales Espinosa E, Corre E, Allam B. Pallial Mucus of the Oyster Crassostrea virginica Regulates the Expression of Putative Virulence Genes of its Pathogen Perkinsus Marinus. Int J Parasitol (2014) 44(5):305-17. doi: 10.1016/j.ijpara.2014.01.006

114. Pales Espinosa E, Koller A, Allam B. Proteomic Characterization of Mucosal Secretions in the Eastern Oyster, Crassostrea virginica. J Proteomics (2016) 132:63-76. doi: 10.1016/j.jprot.2015.11.018

115. Junkunlo K, Söderhäll K, Noonin C, Söderhäll I. PDGF/VEGF-Related Receptor Affects Transglutaminase Activity to Control Cell Migration During Crustacean Hematopoiesis. Stem Cells Dev (2017) 26(20):1449-59. doi: $10.1089 /$ scd.2017.0086

116. Vogt G. How to Minimize Formation and Growth of Tumours: Potential Benefits of Decapod Crustaceans for Cancer Research. Int J Cancer (2008) 123(12):2727-34. doi: 10.1002/ijc.23947

117. Lightner DV, Brock JA. A Lymphoma-Like Neoplasm Arising From Hematopoietic Tissue in the White Shrimp, Penaeus Vannamei Boone (Crustacea: Decapoda). J Invertebrate Pathol (1987) 49(2):188-93. doi: 10.1016/0022-2011(87)90159-5

118. Sparks AK, Morado JF. A Putative Carcinoma-Like Neoplasm in the Hindgut of a Red King Carb, Paralithodes camtschatica. J Invertebrate Pathol (1987) 50(1):45-52. doi: 10.1016/0022-2011(87)90144-3

119. Victor B. Histopathological Progression of Hemic Neoplasms in the Tropical Crab Paratelphusa hydrodromous (Herbst) Treated With Sublethal Cadmium Chloride. Arch Environ Contamination Toxicol (1993) 25(1):4854. doi: $10.1007 / \mathrm{BF} 00230710$

120. Theissinger K, Falckenhayn C, Blande D, Toljamo A, Gutekunst J, Makkonen J, et al. De Novo Assembly and Annotation of the Freshwater Crayfish Astacus astacus Transcriptome. Marine Genomics (2016) 28:7-10. doi: 10.1016/j.margen.2016.02.006

121. Wang Z, Chen YH, Dai YJ, Tan JM, Huang Y, Lan JF, et al. A Novel Vertebrates Toll-like Receptor Counterpart Regulating the Anti-Microbial Peptides Expression in the Freshwater Crayfish, Procambarus clarkii. Fish Shellfish Immunol (2015) 43(1):219-29. doi: 10.1016/j.fsi.2014.12.038

122. Lan JF, Zhao LJ, Wei S, Wang Y, Lin L, Li XC. PcToll2 Positively Regulates the Expression of Antimicrobial Peptides by Promoting PcATF4 Translocation Into the Nucleus. Fish Shellfish Immunol (2016) 58:59-66. doi: 10.1016/j.fsi.2016.09.007

123. Huang Y, Li T, Jin M, Yin S, Hui KM, Ren Q. Newly Identified PcToll4 Regulates Antimicrobial Peptide Expression in Intestine of Red Swamp 
Crayfish Procambarus clarkii. Gene (2017) 610:140-7. doi: 10.1016/ j.gene.2017.02.018

124. Huang Y, Chen Y, Hui K, Ren Q. Cloning and Characterization of Two Toll Receptors (PcToll5 and PcToll6) in Response to White Spot Syndrome Virus in the Red Swamp Crayfish Procambarus clarkii. Front Physiol (2018) 9:936. doi: 10.3389/fphys.2018.00936

125. Habib YJ, Zhang Z. The Involvement of Crustaceans Toll-Like Receptors in Pathogen Recognition. Fish Shellfish Immunol (2020) 102:169-76. doi: $10.1016 /$ j.fsi.2020.04.035

126. Huang Y, Ren Q. Research Progress in Innate Immunity of Freshwater Crustaceans. Dev Comp Immunol (2020) 104:103569. doi: 10.1016/ j.dci.2019.103569

127. Rončević T, Čikeš-Čulić V, Maravić A, Capanni F, Gerdol M, Pacor S, et al. Identification and Functional Characterization of the Astacidin Family of Proline-Rich Host Defence Peptides (PcAst) From the Red Swamp Crayfish (Procambarus clarkii, Girard 1852). Dev Comp Immunol (2020) 105:103574. doi: 10.1016/j.dci.2019.103574

128. Wang XW, Zhang HW, Li X, Zhao XF, Wang JX. Characterization of a Ctype Lectin (PcLec2) as an Upstream Detector in the Prophenoloxidase Activating System of Red Swamp Crayfish. Fish Shellfish Immunol (2011) 55:241-7. doi: 10.1016/j.fsi.2010.10.012

129. Dai Y, Wang Y, Zhao L, Qin Z, Yuan J, Qin Q, et al. A Novel L-type Lectin was Required for the Multiplication of WSSV in Red Swamp Crayfish (Procambarus clakii). Fish Shellfish Immunol (2016) 55:48-55. doi: 10.1016/j.fsi.2016.05.020

130. Wu C, Söderhäll K, Söderhäll I. Two Novel Ficolin-Like Proteins Act as Pattern Recognition Receptors for Invading Pathogens in the Freshwater Crayfish Pacifastacus leniusculus. Proteomics (2011) 11(11):2249-64. doi: $10.1002 /$ pmic. 201000728

131. Ng TH, Kurtz J. Dscam in Immunity: A Question of Diversity in Insects and Crustaceans. Dev Comp Immunol (2020) 105:103539. doi: 10.1016/ j.dci.2019.103539

132. Armitage SAO, Peuß R, Kurtz J. Dscam and Pancrustacean Immune Memory - a Review of the Evidence. Dev Comp Immunol (2015) 48 (2):315-23. doi: 10.1016/j.dci.2014.03.004

133. Lan JF, Zhou J, Zhang XW, Wang ZH, Zhao XF, Ren Q, et al. Characterization of an Immune Deficiency Homolog (IMD) in Shrimp (Fenneropenaeus Chinensis) and Crayfish (Procambarus clarkii). Dev Comp Immunol (2013) 41(4):608-17. doi: 10.1016/j.dci.2013.07.004

134. Huang Y, Ren Q. Molecular Cloning and Functional Analysis of Three STAT Isoforms in Red Swamp Crayfish Procambarus clarkii. Dev Comp Immunol (2020) 108:103670. doi: 10.1016/j.dci.2020.103670

135. Shen H, Hu Y, Ma Y, Zhou X, Xu Z, Shui Y, et al. In-Depth Transcriptome Analysis of the Red Swamp Crayfish Procambarus clarkii. PloS One (2014) 9 (10):e110548. doi: 10.1371/journal.pone.0110548

136. Wu C, Charoensapsri W, Nakamura S, Tassanakajon A, Söderhäll I, Söderhäll K. An MBL-like Protein may Interfere With the Activation of the proPO-system, an Important Innate Immune Reaction in Invertebrates. Immunobiology (2013) 218(2):159-68. doi: 10.1016/j.imbio.2012.02.011

137. Jiravanichpaisal P, Lee SY, Kim YA, Andrén T, Söderhäll I. Antibacterial Peptides in Hemocytes and Hematopoietic Tissue From Freshwater Crayfish Pacifastacus leniusculus: Characterization and Expression Pattern. Dev Comp Immunol (2007) 31(5):441-55. doi: 10.1016/j.dci.2006.08.002

138. Donpudsa S, Rimphanitchayakit V, Tassanakajon A, Söderhäll I, Söderhäll K. Characterization of Two Crustin Antimicrobial Peptides From the Freshwater Crayfish Pacifastacus leniusculus. J Invertebrate Pathol (2010) 104(3):234-8. doi: 10.1016/j.jip.2010.04.001

139. Du ZQ, Li B, Shen XL, Wang K, Du J, Yu XD, et al. A New Antimicrobial Peptide Isoform, Pc-crustin 4 Involved in Antibacterial Innate Immune Response in Fresh Water Crayfish, Procambarus clarkii. Fish Shellfish Immunol (2019) 94:861-70. doi: 10.1016/j.fsi.2019.10.003

140. Zeng Y. Procambarin: A Glycine-Rich Peptide Found in the Haemocytes of Red Swamp Crayfish Procambarus clarkii and its Response to White Spot Syndrome Virus Challenge. Fish Shellfish Immunol (2013) 35(2):407-12. doi: $10.1016 /$ j.fsi.2013.04.048

141. Zhang HW, Sun C, Sun SS, Zhao XF, Wang JX. Functional Analysis of Two Invertebrate-Type Lysozymes From Red Swamp Crayfish, Procambarus clarkii. Fish Shellfish Immunol (2010) 29(6):1066-72. doi: 10.1016/j.fsi.2010.08.023

142. Li X-J, Yang L, Li D, Zhu Y-T, Wang Q, Li W-W. Pathogen Specific Binding Soluble Down Syndrome Cell Adhesion Molecule (Dscam) Regulates Phagocytosis Via Membrane Bound Dscam in Crab. Front Immunol (2018) 9:801. doi: 10.3389/fimmu.2018.00801

143. Li D, Wan Z, Li X, Duan M, Yang L, Ruan Z, et al. Alternatively Spliced Down Syndrome Cell Adhesion Molecule (Dscam) Controls Innate Immunity in Crab. J Biol Chem (2019) 294:16440-50. doi: 10.1074/jbc.RA119.010247

144. Chang YH, Kumar R, Ng TH, Wang HC. What Vaccination Studies Tell Us About Immunological Memory Within the Innate Immune System of Cultured Shrimp and Crayfish. Dev Comp Immunol (2018) 80:53-66. doi: 10.1016/j.dci.2017.03.003

145. Zheng X, Li S, Si Y, Hu J, Xia Y. Locust can Detect $\beta$-1, 3-Glucan of the Fungal Pathogen Before Penetration and Defend Infection via the Toll Signaling Pathway. Dev Comp Immunol (2020) 106:103636. doi: 10.1016/ j.dci.2020.103636

Conflict of Interest: The author declares that the research was conducted in the absence of any commercial or financial relationships that could be construed as a potential conflict of interest.

Copyright (๑) 2021 Bouallegui. This is an open-access article distributed under the terms of the Creative Commons Attribution License (CC BY). The use, distribution or reproduction in other forums is permitted, provided the original author(s) and the copyright owner(s) are credited and that the original publication in this journal is cited, in accordance with accepted academic practice. No use, distribution or reproduction is permitted which does not comply with these terms. 